\title{
Pembuatan Aplikasi Pendukung Keputusan Beasiswa Tidak Mampu Dengan Metode Naive Bayes
}

\author{
Marhalim $^{1}$, AR Walad Mahfuzhi², Sandhi Fernandes 3 \\ 1,2,3 Universitas Muhammadiyah Bengkulus \\ Jalan Bali Kota Bengkulu, 38119 \\ 1 marhalim.harmin@gmail.com, 2 walad.mahfuzhi.gmail.com, 3 \\ sandhy.fernandez@gmail.com
}

Abstract-Decision Support Approval Scholarship Not Capable with Naive Bayes method is created using PHP programming language and MySQL database. This application can assist the Akadmik Administration Bureau and Student Affairs Muhammadiyah University of Bengkulu in completing the work, especially on data management scholarship PPA and BBM and also data archiving. This application can support decision making on PPA and BBM scholarship recipients, in decision making Application use four criteria that is, income of parent, ipk, number of sks and active organization.

Keywords: PHP, Decision Support, Naive Bayes

Abstrak-Aplikasi Pendukung Keputusan Beasiswa Tidak Mampu dengan metode Naive Bayes ini di buat menggunakan bahasa pemrograman PHP dan database MySQL. Aplikasi ini dapat membantu Biro Administrasi Akadmik dan Kemahasiswaan Univeristas Muhammadiyah Bengkulu dalam menyelesaikan pekerjaan khususnya pada pengelolaan data beasiswa PPA dan BBM dan juga pengarsipan data. Aplikasi ini dapat mendukung pengambilan keputusan pada calon penerima beasiswa PPA dan BBM, dalam pengambilan keputusan Aplikasi menggunakan empat kriteria yaitu, penghasilan orang tua, ipk, jumlah sks dan aktif organisasi.

Kata kunci : PHP, Pendukung Keputusan, Naive Bayes.

\section{Pendahuluan}

Pemerintah melalui Direktorat Jenderal Pendidikan Tinggi Kementerian Pendidikan dan Kebudayaan berupaya mengalokasikan dana untuk memberikan Beasiswa Pendidikan bagi mahasiswa yang berprestasi dan pemberian bantuan biaya pendidikan bagi mahasiswa yang memiliki keterbatasan kemampuan ekonomi dalam bentuk Beasiswa dan Bantuan Biaya Pendidikan Peningkatan Prestasi Akademik.

Sejak tahun 2012 istilah Beasiswa Peningkatan Prestasi Akademik (PPA) dan Bantuan Belajar Mahasiswa (BBM) disesuaikan dengan istilah yang sejalan dengan ketentuan perundang-undangan yang ada yaitu menjadi Beasiswa dan Bantuan Biaya Pendidikan Peningkatan Prestasi Akademik (Beasiswa-BBP PPA).

Dari hasil pengumpulan data dengan menayakan lansung ke Biro Administrasi Akademik dan Kemahasiswaan (BAAK) Universitas Muhammadiyah Bengkulu (UMB) didapat informasi bahwa, proses pendataan pendaftar calon penerima beasiswa BBM dan PPA diseleksi oleh masing-masing program studi melalui kriteria yang telah ditentukan, hasil seleksi pendaftar calon penerima beasiswa tersebut sampaikan ke BAAK sebagai lembaga internal yang bertanggung jawab dengan data mahasiswa calon penerima beasiswa untuk diolah dan direkomendasikan ke Kekopertis Wilayah II.

Proses pendataan dan pengelolaan data pendaftar beasiswa oleh BAAK untuk direkomendasikan Kekopertis Wilayah II hanya mengurutkan nilai IPK tertinggi dan dikelompokkan masingmasing program studi akan tetapi belum berdasarkan nilai skor tertinggi dari kriteri-kriteria yang telah ditentukan untuk calon penerima beasiswa ditingkat universitas.

Berdasarkan uraian diatas penulis tertarik untuk mengangkat judul "Pembuatan Aplikasi Pendukung Keputusan Beasiswa Tidak Mampu Dengan Metode Naive Bayes". 


\section{Landasan Teori}

\section{A. Konsep Pembuatan}

Penelitian yang dilakukan adalah untuk mendapatkan informasi yang diperoleh dari pengamatan data-data yang ada dan studi literature. Data dan informasi yang diperoleh dari kegiatan penelitian digunakan untuk . melakukan perancangan dan pembuatan suatu hasil dari sebuah penelitian.

Menurut John Burch dan Gary Grudnitski yang telah diterjamhan oleh Jogiyanto (2006:196) Perancangan adalah penggambaran, perencanaan, dan pembuatan sketsa atau pengaturan dari beberapa elemen yang terpisah dari satu kesatuan yang utuh dan berfungsi[1].

Berdasarkan uraian di atas penulis menyimpulkan bahwa Konsep Pembuatan adalah Tindakan yang terencana guna mendapatkan bentuk dan model yang dapat digunakan.

\section{B. Konsep Aplikasi}

Menurut Jogiyanto (2000:4), aplikasi merupakan program yang berisikan perintah-perintah untuk melakukan pengolahan data. Jogiyanto menambahkan aplikasi secara umum adalah suatu proses dari cara manual yang ditransformasikan ke komputer dengan membuat sistem atau program agar data diolah lebih berdaya guna secara optimal[2].

Menurut Dhanta (2009:32), aplikasi (application) adalah software yang dibuat oleh suatu perusahaan komputer untuk mengerjakan tugas-tugas tertentu, misalnya Microsoft Word, dan Microsoft Exce/3].

Dari pengertian diatas, dapat disimpulkan bahwa konsep aplikasi merupakan software yang ditransformasikan ke komputer yang berisikan perintah-perintah yang berfungsi untuk melakukan berbagai bentuk pekerjaan atau tugas-tugas tertentu seperti penerapan, penggunaan dan penambahan data.

\section{Konsep Pendukung Keputusan}

1) Definisi Keputusan

Menurut Kamus Besar Bahasa Indonesia (Alwi, 2003:575) "Keputusan adalah prihal yang berkaitan dengan putusan atau segala putusan yang telah ditetapkan (sesudah dipertimbangkan, dipikirkan, dan sebagainya)" [4].

Dapat disimpulkan bahwa keputusan itu diambil dengan sengaja, tidak secara kebetulan, dan tidak boleh sembarangan Permasalahannya terlebih dahulu harus diketahui dan dirumuskan dengan jelas, sedangkan pemecahannya harus didasarkan pemilihan alternatif terbaik dari alternatif-alternatif yang disajikan.

Sistem Pedukung Keputusan (SPK) adalah suatu sistem informasi yang dapat membantu mengambil keputusan manajemen dengan mengkobinasikan data, model-model analitik canggih dan piranti, dan perangkat lunak yang ramah penggunaan kedalam satu sistem yang berdaya guna yang bisa mendukung pengambilan keputusan semiterstruktur dan tidak terstruktur. Sistem pengambilan keputusan memberikan penggunanya serangkaian piranti yang fleksibel dan kemampuan untuk menganalisis blok-blok data penting. (C.Laudon dan P.Laudon, 2005:491) [5].

Konsep sistem yang mendukung keputusan dikenal dengan istilah Management Decision Sistem. Sistem tersebut adalah suatu sistem yang berbasis komputer yang ditujukan untuk membantu pengambil keputusan dengan memanfaatkan data dan model tertentu untuk memecahkan berbagai persoalan.

\section{2) Komponen Sistem Pendukung Keputusan}

Menurut Turban dan dkk (2005:17) komponen sistem pendukung keputusan bisa terdiri dari beberapa subsistem, yaitu :

a. Subsistem Manajemen Data (Data Management Subsystem), meliputi basis data, basis data berisi data yang relevan dengan keadaan dan dikelola software yang disebut DBMS (Database Management System).

b. Subsistem Manajemen Model (ModelvManagement Subsystem), berupa sebuah paket software yang berisi model-model finansial, statistik, management science, atau model kwantitatif, yang menyediakan kemampuan analisa dan software management yang sesuai.

c. Subsistem Manajemen Pengetahuan (Knowledge Management Subsystem), merupakan subsistem (optional) yang dapat mendukung subsistem lain atau berlaku sebagai komponen yang berdiri sendiri (independent). 
Subsistem Antarmuka Pengguna (User Interface Subsystem), merupakan subsistem yang dapat dipakai oleh user untuk berkomunikasi dan memberi perintah (menyediakan user interface) [6].

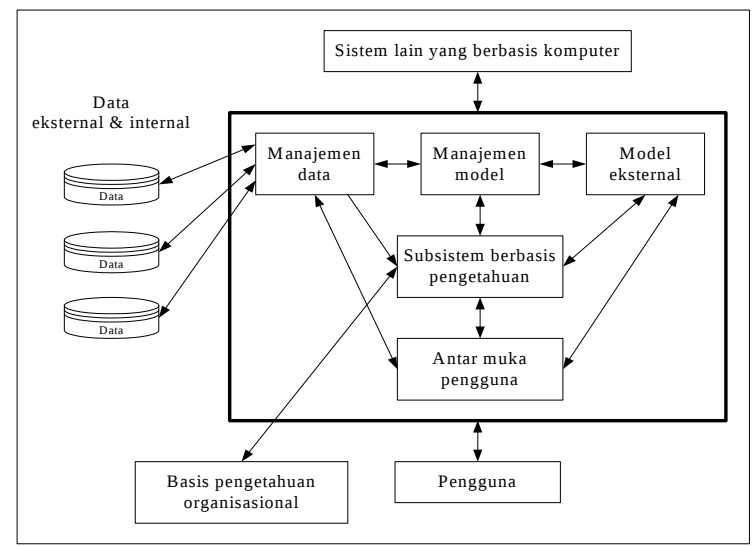

Gambar 1. Arsitektur Sistem Pendukung Keputusan

3) Tahapan Pemodelan Dalam Sistem Pendukung Keputusan

Menurut Turban (2005:2), proses pengambilan keputusan terdiri dari tiga fase proses, yaitu :

a. Studi Kelayakan (Intelligence)

Tahap ini merupakan proses penelusuran dan pendekteksian dari lingkup problematika serta proses pengenalan masalah. Data masukan diperoleh, diproses dan diuji dalam rangka mengidentifikasi masalah.

b. Perancangan (Design)

Tahap ini merupakan proses pengembangan dan pencarian alternatif tindakan/ solusi yang dapat diambil. Tersebut merupakan representasi kejadian nyata yang disederhanakan, sehingga diperlukan proses validasi dan vertifikasi untuk mengetahui keakuratan model dalam meneliti masalah yang ada. c. Pemilihan (Choice)

Tahap ini dilakukan diantara berbagai alternatif solusi yang dimunculkan pada tahap perencanaan agar ditentukan/ dengan memperhatikan kriteria-kriteria berdasarkan tujuan yang akan dicapai.

d. Implementasi (Implementation)

Tahap ini dilakukan penerapan terhadap rancangan sistem yang telah dibuat pada tahap perancangan serta pelaksanaan alternatif tindakan yang telah diplih pada tahap pemilihan.

4) Karakteristik dan Kemampuan Sistem Pendukung Keputusan
Menurut Turban (2005:5) mengatakan bahwa sistem pendukung keputusan mempunyai beberapa karakteristik dan kemampuan, antara lain:

a. SPK menyediakan dukungan bagi pengambil keputusan utamanya pada situasi semi terstruktur dan tak terstruktur dengan memadukan pertimbangan manusia dan informasi terkomputerisasi.

b. Dukungan disediakan untuk berbagai level manajerial yang berbeda, mulai dari pimpinan puncak sampai manajer lapangan, Dukungan disediakan juga bagi individu dan juga bagi grup.

c. SPK menyediakan dukungan ke berbagai keputusan yang berurutan atau saling berkaitan.

d. Mampu memberikan dukungan keputusan melalui beberapa fase yaitu intelligence, design, choice dan implementation.

e. SPK selalu bisa beradaptasi. Pengambil keputusan harus reaktif, mampu mengatasi perubahan kondisi secepat mungkin dan beradaptasi untuk membuat SPK selalu bisa menangani perubahan.

f. SPK mudah digunakan, Pengguna harus merasa nyaman dengan system karena itu sistem harus mempunyai dukungan grafis yang baik, antar muka yang mudah bersahabat, sehingga menjadi sistem yang interaktif.

g. Pengambil keputusan memiliki kontrol menyeluruh terhadap proses pengambilan keputusan dalam menyelesaikan masalah. SPK secara khusus ditujukan untuk mendukung dan tidak menggantikan pengambil keputusan.

h. Pengambil keputusan dapat menindaklanjuti rekomendasi dari SPK untuk digunakan atau tidak digunakan.

\section{Konsep Beasiswa Tidak Mampu}

Undang-undang Nomor 20 Tahun 2003 tentang Sistem Pendidikan Nasional, Bab $V$ pasal 12 (1.c), menyebutkan bahwa setiap peserta didik pada setiap satuan pendidikan berhak mendapatkan beasiswa bagi yang berprestasi yang orang tuanya tidak mampu membiayai pendidikannya. Pasal 12 (1.d), menyebutkan bahwa setiap peserta didik pada setiap satuan pendidikan berhak mendapatkan biaya pendidikan bagi mereka yang orang 
tuanya tidak mampu membiayai pendidikannya. Selain itu di dalam Undang-undang Nomor 12 Tahun 2012 tentang Pendidikan Tinggi di dalam Pasal 76 Ayat (2) juga jelas mengamanahkan tentang pemenuhan hak Mahasiswa yaitu pemerintah harus memberikan (a) beasiswa kepada Mahasiswa berprestasi; (b) bantuan atau membebaskan biaya Pendidikan; dan/atau (c) pinjaman dana tanpa bunga yang wajib dilunasi setelah lulus dan/atau memperoleh pekerjaan.

Dijelaskan lebih lanjut di dalam penjelasan, yang dimaksud dengan "beasiswa" adalah dukungan biaya Pendidikan yang diberikan kepada Mahasiswa untuk mengikuti dan/atau menyelesaikan Pendidikan Tinggi berdasarkan pertimbangan utama prestasi dan/atau potensi akademik. Sedangkan "bantuan biaya pendidikan" adalah dukungan biaya Pendidikan yang diberikan kepada Mahasiswa untuk mengikuti dan/atau menyelesaikan Pendidikan Tinggi berdasarkan pertimbangan utama keterbatasan kemampuan ekonomi (Pedoman Beasiswa dan Bantuan Biaya Pendidikan PPA, 2014:1). [7]

Dari uraian diatas dapat disimpulkan bahwa konsep Beasiswa Tidak Mampu adalah Pemerintah memberikan bantuan biaya pendidikan kepada peserta didik bagi orang tua atau wali yang tidak mampu membiayai pendidikan anaknya untuk dapat menyeselasai pendidikan dan pemerintah memberikan hak dari setiap warga Negara untuk kecerdasan.

\section{E. Metode Naïve Bayes}

1) Definisi Naive Bayes Classifier (NBC)

Naive Bayes Classifier (NBC) merupakan Naive Bayes merupakan teknik prediksi berbasis probabilistik sederhana yang berdasar pada penerapan teorema Bayes (aturan Bayes) dengan asumsi independensi (ketidaktergantungan) yang kuat (naif). Dengan kata lain, dalam Naive Bayes model yang digunakan adalah "model fitur independen" (IJNS, 2014:46).

Formulasi Naive Bayes untuk klasifikasi adalah

Dimana :

- $\mathrm{P}(\mathrm{Y} \mid \mathrm{X})$ adalah probabilitas data dengan vector $X$ pada kelas $Y$.

- $P(Y)$ adalah probabilitas awal kelas Y.
- adalah probabilitas independen kelas $Y$ dari semua fitur dalam vector $X$.

Umumnya, Bayes mudah dihitung untuk fitur bertipe kategoris seperti pada kasus fitur "jenis kelamin" dengan nilai (pria,wanita) namun untuk fitur numerik ada perlakuan khusus sebelum dimasukkan dalam Naive Bayes. Caranya adalah :

a. Melakukan diskretisasi pada setiap fitur kontinu dan mengganti niai fitur kontinu tersebut dengan nilai interval diskret. Pendekatan ini dilakukan dengan mentransformasikan fitur kontinu ke dalam fitur ordinal.

b. Mengasumsikan bentuk tertentu dari distribusi probabilitas untuk fitur kontinu dan memperkirakan parameter distribusi dengan data pelatihan. [8]

\section{2) Karakteristik Naive Bayes}

Klasifikasi dengan Naive Bayes bekerja berdasarkan teori probabilitas yang memandang semua fitur dari data sebagai bukti dalam probabilitas. Hal ini memberikan karakteristik Naive Bayes sebagai berikut :

a. Metode Naive Bayes bekerja teguh (robust) terhadap data-data yang terisolasi yang biasanya merupakan data dengan karakteristik berbeda (outliner). Naive Bayes juga bisa menangani nilai atribut yang salah dengan mengabaikan data latih selama proses pembangunan model dan prediksi.

b. Tangguh menghadapi atribut yang tidak relevan.

c. Atribut yang mempunyai korelasi bisa mendegradasi kinerja klasifikasi Naïve Bayes karena asumsi independensi atribut tersebut sudah tidak ada.

3) Konsep Klasifikasi

Klasifikasi merupakan suatu pekerjaan menilai objek data untuk memasukkannya ke dalam kelas tertentu dari sejumlah kelas yang tersedia. Dalam klasifikasi ada dua pekerjaan utama yang dilakukan, yaitu : pertama, Pembangunan model sebagai prototype untuk disimpan sebagai memori dan kedua, Penggunaan model tersebut untuk melakukan pengenalan/ klasifikasi/ prediksi pada suatu objek data lain agar diketahui di kelas mana objek data tersebut dalam model yang mudah disimpan. 
Contoh aplikasi yang sering ditemui adalah pengklasifikasian jenis hewan, yang mempunyai sejumlah atribut. Dengan atribut tersebut, jika ada hewan baru, kelas hewannya bisa langsung diketahui. Contoh lain adalah bagaimana melakukan diagnosis penyakit kulit kanker melanoma (Amaliyah et al, 2011), yaitu dengan melakukan pembangunan model berdasarkan data latih yang ada, kemudian menggunakan model tersebut untuk mengidentifikasi penyakit pasien baru sehingga diketahui apakah pasien tersebut menderita kanker atau tidak.

4) Model Klasifikasi

Model dalam klasifikasi mempunyai arti yang sama dengan kotak hitam, dimana ada suatu model yang menerima masukan, kemudian mampu melakukan pemikiran terhadap masukan tersebut dan memberikan jawaban sebagai keluaran dari hasil pemikirannya. Kerangka kerja (framework) klasifikasi ditunjukan pada gambar 2. pada gambar tersebut disediakan sejumlah data latih $(x, y)$ untuk digunakan sebagai data pembangunan model. Model tersebut kemudian dipakai untuk memprediksi kelas dari data uji $(x, y)$ sehingga diketahui kelas $y$ yang sesungguhnya.

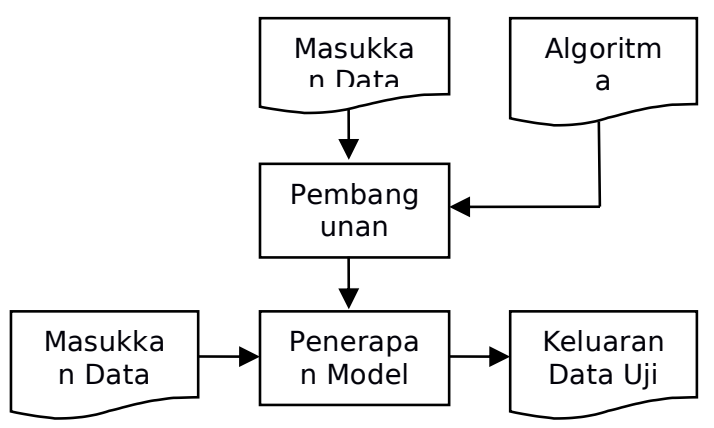

Gambar 2. Proses Klasifikasi

Model yang sudah dibangun pada saat pelatihan kemudian dapat digunakan untuk memprediksi label kelas baru yang belum diketahui. Dalam pembangunan model selama proses pelatihan tersebut diperlukan suatu algoritma untuk membangunnya, yang disebut algoritma pelatihan (/earning algorithm). Ada banyak algoritma pelatihan yang sudah dikembangkan oleh para peneliti, seperti K-Nearest Neighbor, Artificial Neural Network, Support II-6 Vector Machine dan sebagainya. Setiap algoritma mempunyai kelebihan dan kekurangan, tetapi semua algoritma berprinsip sama, yaitu melakukan suatu pelatihan sehingga di akhir pelatihan, model dapat memetakan (memprediksi) setiap vektor masukan ke label kelas keluaran dengan benar.

\section{F. DataBase Management System}

Menurut Kusumadewi dan Purnomo ( 2004 : 189 ) "Basis data (database) merupakan kumpulan dari data yang saling berhubungan satu dengan yang lainnya, tersimpan didalam perangkat keras komputer dan digunakan perangkat lunak untuk memanipulasinya. Sistem basis data (database system) adalah suatu sistem informasi yang mengintegrasikan kumpulan data yang saling berhubungan satu dengan yang lainnya dan membuatnya tersedia untuk beberapa aplikasi dalam suatu organisasi.

Adapun istilah yang sering digunakan dalam perancangan database adalah sebagai berikut :

a. Entity adalah tempat, orang atau kejadian serta konsep yang informasinya direkam

b. Atribut adalah elemen data yang menunjang suatu entity

c. Data value adalah data actual yang disimpan pada sebuah atribut

d. Record adalah kumpulan elemen yang saling berkaitan yang menginformasikan suatu entity yang lengkap

e. File adalah kumpulan record yang sejenis dimana panjang elemen sama, atribut yang sama dan data value yang berbeda datanya.

f. Database adalah kumpulan dan file yang membentuk suatu bangunan [9].

\section{G. Bahasa Pemrograman PHP}

Menurut Peranginangin (2006:2) PHP adalah suatu bahasa script server-side dalam pengembangan Web yang disisipkan dalam dokumen HTML.

Penggunaan PHP memungkinkan Web dapat dibuat dinamis sehingga maintenance situs Web tersebut menjadi lebih mudah dan efisien. PHP merupakan software open-source yang disebarkan dan dilisensikan secara gratis serta dapat didwonload bebas[10].

\section{H. Database MySQL}

Menurut Wahana (2010:5) MySQL adalah sebuah program database yang mampu mengirim dan menerima dengan sangat cepat dan multi user. MySQL 
memiliki dua bentuk lensensi, yaitu free software dan shareware[11].

\section{Data Flow Diagram (DFD)}

Menurut Tata (2012:116) pengertian Data Flow Diagram (DFD) adalah suatu network yang menggambarkan suatu system automat/komputerisasi, manualisasi atau gabungan dari keduanya, yang gambarannya disusun dalam kumpulan komponen sistem yang saling berhubungan sesuai dengan aturannya. keuntungan penggunaan DFD adalah memungkinkan untuk menggambarkan sistem dari level yang lebih tinggi kemudian menguraikannya menjadi level yang lebih rendah (dekomposisi). Sedangkan kekurangan menggunakan DPF adalah tidak menunjukan proses pengulangan (looping), proses keputusan dan proses perhitungan[12].

\section{J. Entity Relationship Diagram (ERD)}

Menurut Wahyudi (2008:199)

Database digunakan untuk menyimpan data yang terstruktur, struktur data dapat didesain menggunakan beberapa variasi teknik, satu diantaranya disebut dengan Entity Relationship Modelling atau ERM. Model ERM pada mulanya disamapaikan oleh peter pada tahun 1976 sebagai suatu cara untuk menyatkan jaringan dan menggambarkan relational database, singkatnya model ERM adalah sebuah model konseptual dari data yang menggambarkan keadaan sebenarnya dari entity dan Relationship[13].

Hasil akhir dari proses ERM adalah Entity Relationship Diagram atau ERD. Model data membutuhkan notasi grafis untuk mempresentasikannya. ERD adalah tipe dari model data konseptual atau semantic data model, ada dua jenis penggambaran ERD, yaitu (1) binary relationship (ada lebih dari satu entitas), (2) recursive relationship (hanya ada satu entitas). Ada tiga macam relasi antar entitas dalam ERD binary relationship, yaitu :

a. One-to-one : satu elemen di entitas (A) tepat bersosiasi dengan satu elemen di entitas (B). contoh : pegawai dengan workstation.

b. One-to-many : satu elemen di entitas (A) bersosiasi dengan nol, satu atau lebih elemn yang ada di entitas (B), tetapi untuk satu elem di entitas (B) hanya berelasi dengan satu elemen di entitas (A). contoh : Departemen dengan Projek.

c. Many-to-many : satu elemen di entitas $(A)$ bersosiasi dengan nol, satu atau lebih elemen di entitas (B), dan satu elemen di entitas (B) bersosiaso dengan nol, satu atau lebih elemen di entitas (A). Contoh : Pegawai dengan Projek.

ERD merupakan alat untuk pembuatan model data secara grafik, maka ERD memiliki simbol-simbol yang digunakan untuk menggambarkan model data seperti terdapat pada tabel berikut:

\section{K. Flowchart Sistem}

Menurut Jugiyanto 2006: 802 Bagan alir program (program flowchart) Bagan alir program (program flowchart) merupakan bagan yang menjelaskan secara rinci langkahlangkah dari proses program. Bagan alir program dibuat dengan menggunakan simbol-simbol sebagai berikut ini.

\section{Metodologi Penelitian}

\section{A. Metode Pengumpulan Data}

Pada penelitian ini penulis melakukan pengumpulan data antara lain :

1) Metode Observasi

Metode Observasi yaitu melakukan penelitian secara langsung ketempat yang menjadi objek penelitian.

2) Metode Wawancara

Yaitu melakukan proses tanya jawab secara lisan yang berhubungan dengan objek yang diteliti pada pihak-pihak yang bersangkutan yang dalam hal ini di Biro Administrasi Akademik dan Kemahasiswaan Universitas Muhammadiyah Bengkulu.

3) Metode Studi Pustaka

Penulis melakukan pengumpulan tidak hanya mengamati dan melakukan wawancara, tapi penulis juga mengumpulkan data melewati artikel, buku, dan bahan dari internet yang berkaitan dengan penelitian sebagai teori pendukung.

\section{B. Pengembangan Sistem}

Struktur pengembangan sistem yang digunakan Penulis adalah waterfall, yaitu setiap tahap harus diselesaikan terlebih dahulu secara penuh sebelum diteruskan ke tahap berikutnya untuk menghindari terjadinya pengulangan tahapan.

Menurut Tata Sutabri dalam bukunya yang berjudul Analisa Sistem Informasi 
mengatakan bahwa: "waterfall adalah struktur pengembangan sistem dimana setiap tahap harus diselesaikan terlebih dahulu secara penuh sebelum diteruskan ke tahap berikutnya untuk menghindari terjadinya pengulangan tahapan". (Sutabri, 2004:62-63) [14].

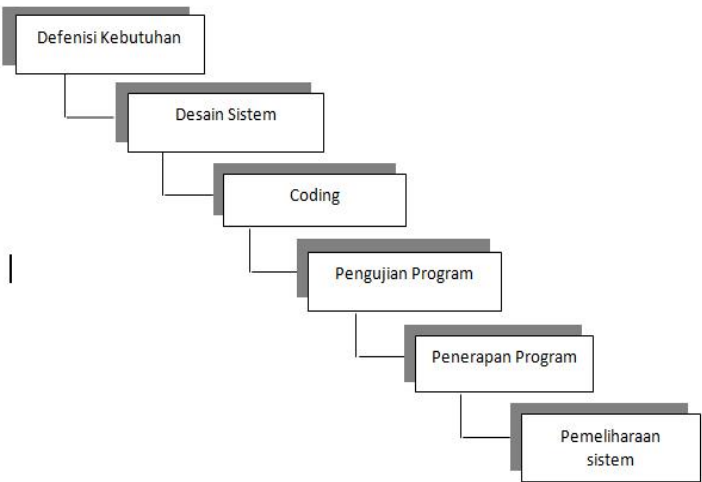

Gambar 3. Model Waterfall (Sutabri, 2004)

Kebutuhan informasi pada sistem implementasi dalam Aplikasi Pendukung Keputusan Beasiswa Tidak Mampu Dengan Metode Naive Bayes yang diusulkan adalah :

1) Klasifikasi

Berikut merupakan dua klasifikasi data yang dibutuhkan dalam penduung pengambilan keputusan beasiswa tdak mampu adalah sebagai berikut :

(1) Beasiswa BBM

(1) Beasiswa PPA

2) Kriteria Yang Dibtuhkan

Adapun Kriteria yang di butuhkan untuk pengambilan keputusan berdasarkan alternatif yang telah ditentukan yaitu :

TABEL 1

Kriteria Beasiswa

\begin{tabular}{|c|l|}
\hline No & \multicolumn{1}{|c|}{ Kriteria } \\
\hline 1 & Penghasilan orang tua \\
\hline 2 & IPK \\
\hline 3 & Jumlah sks yang telah diambil \\
\hline 4 & Keaktifan di organisasi \\
\hline
\end{tabular}

3) Range Alternatif Kriteria

TABEL 2

Range Alternatif Kriteria Penghasilan Orangtua

\begin{tabular}{|c|l|}
\hline $\begin{array}{c}\text { Alternati } \\
\text { f }\end{array}$ & $\begin{array}{l}\text { Range Penghasilan } \\
\text { orang tua }\end{array}$ \\
\hline Rendah & $<1.500 .000$ \\
\hline Sedang & $1.500 .000-3.000 .000$ \\
\hline Tinggi & $>3.000 .000$ \\
\hline
\end{tabular}

4) Range Alternatif Kriteria IPK

TABEL 3

Range Alternatif Kriteria IPK

\begin{tabular}{|c|c|}
\hline $\begin{array}{c}\text { Alternati } \\
\mathbf{f}\end{array}$ & Range IPK \\
\hline Rendah & $<3.00$ \\
\hline Sedang & $3.00-3.50$ \\
\hline Tinggi & $>3.5$ \\
\hline
\end{tabular}

5) Range Alternatif Kriteria SKS

TABEL 4

Range Alternatif Kriteria SKS

\begin{tabular}{|c|c|}
\hline $\begin{array}{c}\text { Alternati } \\
\mathbf{f}\end{array}$ & Range SKS \\
\hline Sedikit & $<24$ \\
\hline Sedang & $25-72$ \\
\hline Banyak & $>72$ \\
\hline
\end{tabular}

6) Range Alternatif Kriteria Aktif Organisasi

TABEL 5

Range Alternatif Kriteria Aktif Organisasi

\begin{tabular}{|c|c|}
\hline Alternatif & $\begin{array}{c}\text { Range Aktif Organisasi } \\
\text { (Jumlah Sertifikat) }\end{array}$ \\
\hline Tidak Aktif & $<2$ \\
\hline Sedang & 2 \\
\hline Aktif & $>2$ \\
\hline
\end{tabular}

\section{Data Flow Diadram}

Data flow diagram digunakan untuk enggambarkan proses dari suatu sistem yang akan dibuat.

1) Diagram Konteks

Diagram konteks dari Sistem Pendukung Keputusan Beasiswa Tidak Mampu dapat dilihat pada gambar 4.

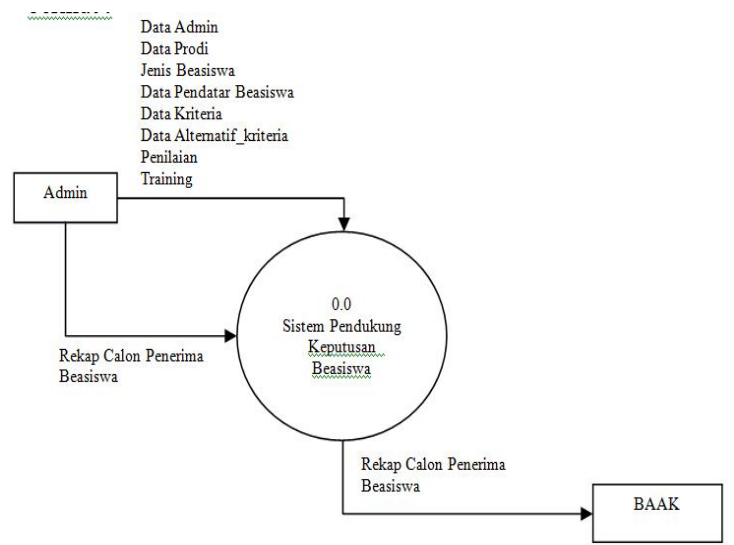

Gambar 4. Diagram Konteks 
2) Hierarki Plus Input Process dan Output Gambar Hierarki Plus Input Process dan Output dari Sistem Aplikasi Pendukung Keputusan Beasiswa Tidak Mampu pada gambar 5.

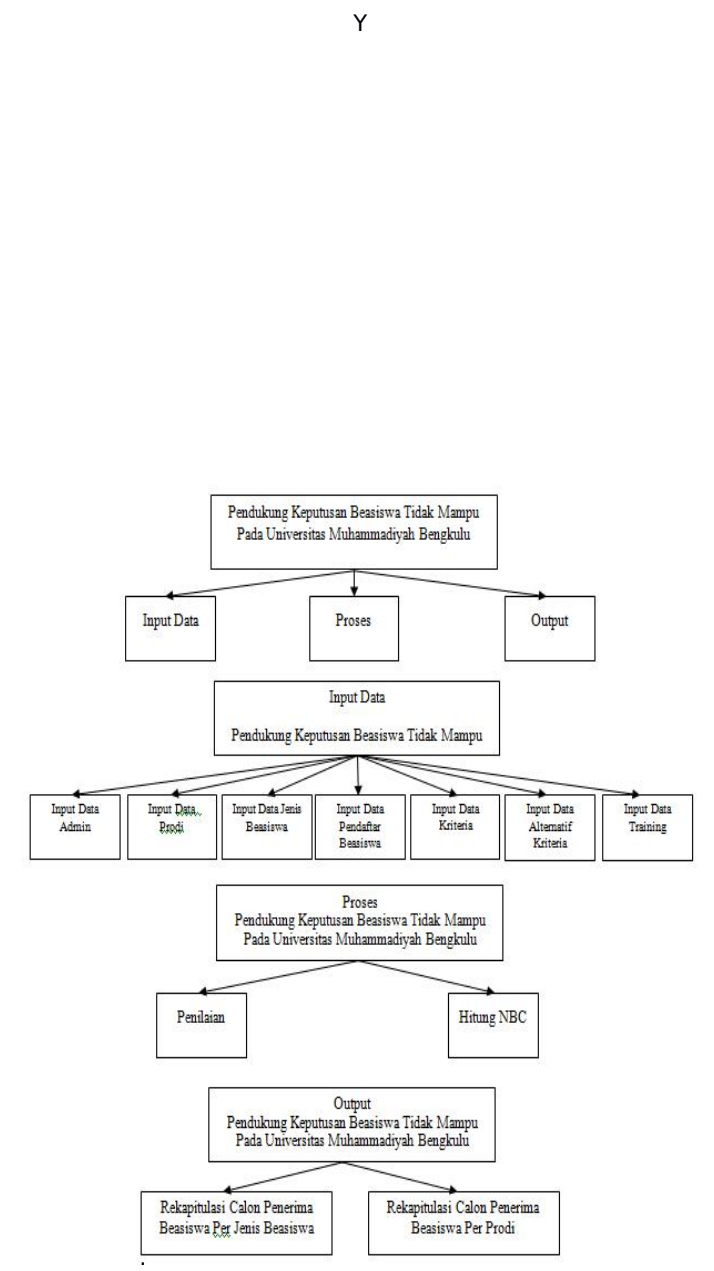

Gambar 5. Hierarki Plus Input Process dan Output

\section{Hasil dan Pembahasan}

A. Hasil Aplikasi Pendukung Keputusan Beasiswa Tidak Mampu

Berdasarkan dari perancangan sistem, dihasilkan Aplikasi Pendukung Keputusan Beasiswa Tidak Mampu menggunakan bahasa pemrograman PHP dan aplikasi database MySQL. Pada Aplikasi Pendukung Keputusan Beasiswa Tidak Mampu terdiri dari empat menu dari menu utama diantaranya menu admin yang terdiri dari data admin dan logout. Menu input data yang terdiri menu prodi, jenis beasiswa, kriteria, alternaif kriteria dan pendaftar. Menu proses terdiri dari menu penilaian dan menu hitung naïve bayes. Menu output yang terdiri dari menu laporan perjenis beasiswa dan menu laporan per program studi.

Aplikasi Pendukung Keputusan Beasiswa Tidak Mampu ini telah dirancang sesuai dengan proposal. Aplikasi ini dapat diaktifkan melalui localhost windows internet exsplorer dengan alamat http://localhost/beasiswa/index.php?adm =login. Gambar 6 dan tujuh adalah contoh dari aplikasi.

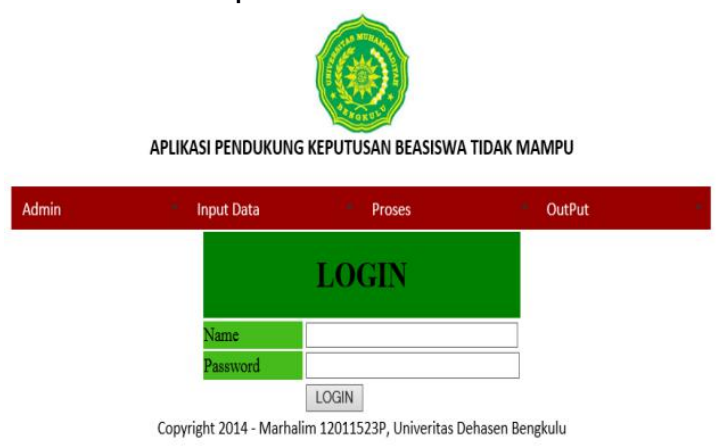

Gambar 6. Tampilan Menu Utama

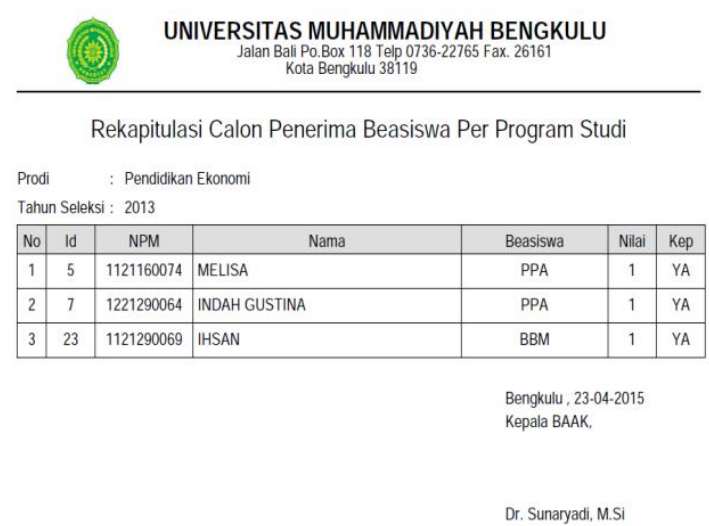

Gambar 7. Hasil Print Out Menu Lap Per Prodi

\section{B. Hasil Pegujian Sistem}

Pengujian Aplikasi Pendukung Keputusan Beasiswa Tidak Mampu Black Box. Merupakan pengujian yang berfokus pada spesifikasi fungsional dari perangkat lunak, tester dapat mendefinisikan kumpulan kondisi input dan melakukan pengetesan pada spesifikasi fungsional program.

Dalam pengujian aplikasi ini dilakukan dengan empat tahapan :

1) Pengujian Interface Sistem

Pengujian fungsi interface sistem bertujuan untuk mengetahui fungsional dari elemen-elemen yang terdapat dalam sistem. Elemen- elemen interface yang diujikan adalah elemen button. 
2) Pengujian Fungsi Dasar Sistem

Pengujian Fungsi Dasar Sistem bertujuan untuk mengetahui kerja dari fungsi-fungsi dasar dalam sistem yang pada akhirnya membentuk modul khusus.

3) Pengujian Form Handle Sistem

Pengujian Form Handle Sistem bertujuan untuk mengetahui kemampuan system untuk menangani macam-macam input yang diberikan user.

4) Pengujian Keamanan Sistem

Pengujian Keamanan Sistem bertujuan untuk mengetahui aspek keamanan yang dimiliki sistem.

\section{Penutup}

A. Kesimpulan

Berdasarkan hasil pengamatan yang telah dilakukan dalam Pembuatan Aplikasi Pendukung Keputusan Beasiswa Tidak Mampu metode Niave Bayes dapat disimpulkan sebagai berikut :

1) Program ini mampu memberikan hasil pengambilan keputusan kepada calon penerima beasiswa PPA dan BBM.

2) Program ini mampu memberikan kemudahan dan ketelitian dalam hal pengelolaan data.

3) Program ini dapat membantu Biro Administrasi Aakadmik dan Kemahasiswaan Univeristas Muhammadiyah Bengkulu dalam menyelesaian pekerjaan khususnya pada proses beasiswa PPA dan BBM dan juga pengarsipan data.

B. Saran

Berdasarkan pembahasan dan kesimpulan yang telah diuraikan di atas, saran yang dapat diberikan adalah dengan adanya aplikasi ini diharapkan Agar pemilihan calon penerima beasiswa dapat lebih mudah tanpa harus menilai secara manual, maka perlu kiranya adanya program yang mampu diakses secara Online dari manapun yang dalam hal ini dapat diwakili oleh Universitas Muhammadiyah Bengkulu

\section{Referensi}

[1] Jogiyanto, Analisis dan desain Sistem Informasi, Andi Publisher, Yogyakarta, 2006.

[2] Jogiyanto, Pengenalan Komputer, C.V.ANDI OFFSET, Yogyakarta, 2000.
[3] Dhanta, Pengantar IImu Komputer, INDAH, Surabaya, 2009.

[4] Alwi, Kamus Besar Bahasa Indonesia Edisi Ketiga, Balai Pustaka, Jakarta, 2003.

[5] Kenneth C. Laudon dan Jane P. Laudon, Sistem Informasi manajemen Mengelola Perusahaan Digital Edisi 8, Yogyakarta, 2005.

[6] Turban, E., dkk., Decision Support systems and Intelligent Systems Edisi 7 jilid 1, Andi, Yogyakarta, 2005.

[7] Direktur Pembelajaran dan Kemahasiswaan, Pedoman Beasiswa dan Bantuan Biaya Pendidikan PPA 2014, Jakarta, 2014.

[8] IJNS, Indonesian Journal on Networking and Security, Volume 3 No 2, http://ijns.org, SSN: 2302-5700, 2014.

[9] Kusumadewi \& Purnomo, Aplikasi Logika Fuzzy Untuk Pendukung Keputusan, Graha IImu, Yogyakarta, 2004.

[10]Peranginangin, Aplikasi Web Dengan PHP dan MySQL, Yogyakarta, 2006.

[11]Wahana, Panduan Belajar MySQL Database Server, Mediakita, Jakarta, 2010.

[12]Tata, Konsep Sistem Informasi. Andi, Yogyakarta, 2012.

[13]Wahyudi, Konsep Sistem Informasi dari Bit sampaike database, Andi Publisher, 2008.

[14]Tata, Analisa Sistem Informasi. Edisi Pertama, Andi, Yogyakarta, 2004. 